\title{
PERAN MEDIASI KEGUNAAN PERSEPSIAN PADA KEPUASAN PENGGUNA SISTEM INFORMASI KEUANGAN DAERAH
}

\author{
Sendy Cipta Utama, Bambang Purnomosidhi, \& Wuryan Andayani \\ Universitas Brawijaya, Indonesia \\ Email: esyghonz@gmail.com
}

\begin{abstract}
Abstrak: Peran Mediasi Kegunaan Persepsian pada Kepuasan Pengguna Sistem Informasi Keuangan Daerah. Penelitian ini bertujuan untuk membuktikan secara empiris pengaruh kualitas sistem, kualitas informasi, kualitas layanan dan kegunaan persepsian terhadap kepuasan pengguna Sistem Informasi Keuangan Daerah (SIKD). Penelitian ini juga menguji peran mediasi kegunaan persepsian pada pengaruh kualitas sistem, kualitas informasi, kualitas layanan terhadap kepuasan pengguna SIKD. Teknik analisis menggunakan SEM (Structural Equation Modelling). Data didapatkan dari 147 staff pengelola keuangan daerah di seluruh Satuan Kerja Perangkat Daerah (SKPD) di Pemerintah Kota Batu. Sampel dipilih dengan metode judgment sampling. Hasil penelitian menunjukkan semakin baik kualitas informasi dan semakin tinggi kepercayaan pengguna bahwa sistem informasi bermanfaat akan meningkatkan kepuasan pengguna. Selanjutnya, Informasi yang berkualitas akan meningkatkan kepercayaan penggunanya bahwa informasi yang digunakan sebagai dasar pengambilan keputusan semakin baik sehingga berdampak pada meningkatnya kepuasan pengguna.
\end{abstract}

Kata kunci: Kualitas Sistem, Kualitas Informasi, Kualitas Layanan, Kegunaan Persepsian, Kepuasan Pengguna

\begin{abstract}
The Role of Perceived Usefulness on User Satisfaction of Regional Finance Information System. This study aims to investigate empirically the influence of system quality, information quality, service quality and perceived usefulness on user satisfaction of the Regional Finance Information System. This study also examines the role of perceived usefulness on the effect of system quality, information quality, service quality on user satisfaction. Analysis technique using SEM (Structural Equation Modelling). Data were gathered from 147 staff of the finance management on all Regional Unit in Pemerintah Kota Batu. The samples selected by judgment sampling method. The findings show that the better of information quality and the higher of the user's perceived that the information systems were useful will increase user satisfaction. In addition, information quality will increase user trust on its support to decision making. Thus, will effect on the increase of user satisfaction.
\end{abstract}

Keyword: System Quality, Information Quality, Service Quality, Perceived Usefulness, User Satisfaction

\section{PENDAHULUAN}

Beberapa dekade terakhir menunjukkan kemajuan dunia digital dan perkembangan sistem informasi yang sangat cepat. Kepuasan pengguna sistem informasi menjadi fenomena menarik untuk diteliti karena menjadi ukuran keberhasilan implementasi sistem informasi. Kepuasan pengguna dapat didefinisikan sebagai perasaan akhir berupa rasa senang atau tidak senang yang dihasilkan interaksi dengan sistem (Seddon dan Kiew, 1996). Doll dan Torkzadeh (1988) menyatakan kepuasan pengguna ini penting karena sukses tidaknya 


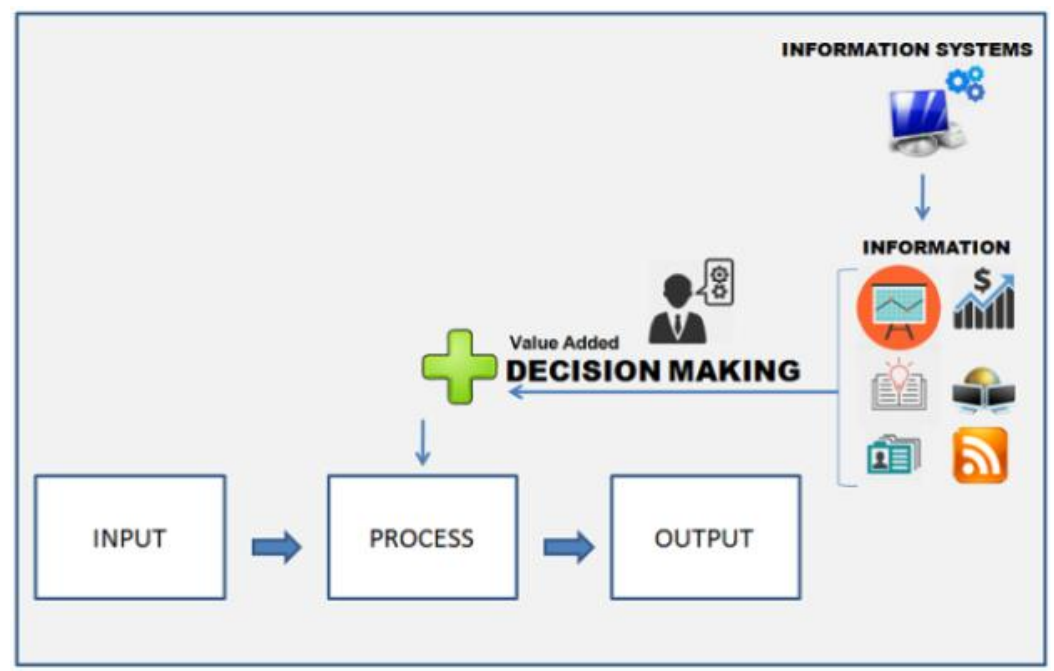

Gambar 1. Sistem informasi bagi organisasi

implementasi sistem informasi diukur dari tingkat kepuasan pengguna. Jika pengguna tidak puas, implementasi sistem informasi dapat dikatakan gagal. Kegagalan sistem informasi akan menghasilkan informasi yang tidak efektif sehingga keputusan yang diambil manajemen tidak memberikan nilai tambah bagi organisasi.

Hartono (2007:15) mengungkapkan dewasa ini organisasi sudah mulai bergantung pada sistem teknologi informasi sebagai bagian dari strategi untuk meningkatkan produktivitas organisasi. Rangkaian informasi diproduksi oleh sebuah sistem yang dikenal dengan sistem informasi berbasis teknologi. Keuntungan bagi organisasi bisa dicapai jika penyelenggaraan sistem informasi benar-benar sukses.
Pentingnya sistem informasi bagi organisasi ditunjukkan seperti pada Gambar 1.

Saat ini sistem informasi berbasis teknologi menjadi roda penggerak kegiatan organisasi baik publik ataupun private, namun kegagalan sistem informasi kerap terjadi. Beberapa kegagalan sistem informasi di sektor publik yang berhasil direkam oleh media ditunjukkan pada Tabel 1.

Paska reformasi tuntutan masyarakat atas transparansi dan akuntabilitas publik terhadap kegiatan pemerintahan cukup masif. Konsep yang diusung adalah tata kelola pemerintahan yang baik (Good Governance) sehingga negara berperan memberikan pelayanan demi kesejahteraan rakyat dengan sistem peradilan yang baik dan sistem pemerintahan yang dapat dipertanggungjawabkan kepada publik.

Tabel 1. Kegagalan Sistem Informasi

\begin{tabular}{cl}
\hline No & \multicolumn{1}{c}{ Kegagalan Sistem Informasi } \\
\hline 1. & Gangguan Sistem Layanan Pengadaan Secara Elektronik (LPSE) di Provinsi Kalimantan \\
& Utara (2014). Menyebabkan jadwal lelang mundur dan pembangunan tidak tepat waktu \\
2. & Gangguan server e-KTP di Subang (2014). \\
3. & Gangguan sistem informasi kepabeanan dan cukai (CIESA). Kegiatan ekspor-impor \\
& terhambat \& biaya logistik meningkat (2016) \\
4. & Gangguan Sistem Perbendaharaan dan Anggaran Negara (SPAN) tahun 2016. \\
5 & Gangguan sistem aplikasi database kendaraan bermotor di Samsat Lampung (2016). \\
\hline
\end{tabular}


Tidak hanya di pemerintah pusat, pemerintah daerah sebagai otoritas pengelola dana publik juga dituntut menerapkan prinsip transparan, efektif, efisien, dan dapat dipertanggungjawabkan. Hal tersebut dapat terwujud jika pemerintah daerah bisa mentransformasi kegiatan pengelolaan keuangan yang dulunya dilakukan secara manual menjadi otomatis berbasis sistem teknologi informasi.

Untuk membantu proses pengelolaan keuangan daerah, pemerintah melalui Undang-Undang No.33 tahun 2004 dan Peraturan Pemerintah No.56 Tahun 2005 menyelenggarakan Sistem Informasi Keuangan Daerah (SIKD) secara nasional. Dalam peraturan pemerintah di atas disebutkan bahwa SIKD adalah sebuah sistem yang mendokumentasikan, mengadministrasikan, serta mengolah data pengelolaan keuangan daerah dan data terkait lainnya menjadi informasi yang disajikan kepada masyarakat dan sebagai bahan pengambilan keputusan dalam rangka perencanaan, pelaksanaan, dan pelaporan pertanggungjawaban pemerintah daerah.

Seiring dengan berjalannya waktu, berkembangnya peraturan, kebutuhan, dan dinamika lingkungan tempat SIKD berada, pengguna SIKD dihadapkan pada perasaan tidak puas terhadap penyelenggaraan SIKD karena akses yang lambat dan keluaran informasi laporan keuangan tidak akurat. Sebagian besar disebabkan kesalahan input data oleh operator, perangkat komputer $(P C)$, server, jaringan yang tidak memadai, dan aplikasi tidak berfungsi. Kendala tersebut dapat menyebabkan ketidakpuasan penggunanya.
Kegagalan sistem informasi disebabkan oleh kesalahan-kesalahan teknis hardware, software, kesalahan pengguna, penyedia layanan serta adanya persepsi keraguan individu bahwa sistem informasi tidak dapat meningkatkan kinerjanya. Banyak sistem informasi gagal karena aspek teknisnya, yaitu kualitas teknis sistem teknologi informasi yang buruk dan banyak mengandung kesalahan-kesalahan sintak, kesalahankesalahan logik, dan bahkan kesalahankesalahan informasi (Hartono, 2007:1). Hartono (2007:1) juga mengungkapkan walaupun kualitas teknis sistem informasi sudah membaik, masih juga terdengar banyak sistem informasi yang gagal diterapkan. Oleh karena itu, diperlukan pengukuran kesuksesan implementasi sistem informasi, yang nantinya hasil pengukuran digunakan untuk perbaikan SIKD di masa depan.

Motivasi penelitian dan isu penting yang mendasari dilakukannya penelitian ini yaitu, pertama, pengukuran kesuksesan sistem informasi yang efektif seperti biaya-manfaat sulit dilakukan karena tidak semua manfaat dapat dikuantifikasi, kedua, adanya kegagalan sistem informasi, ketiga, adanya konflik signifikansi pada hasil penelitianpenelitian terdahulu. Konflik signifikansi dan arah ditunjukkan seperti pada penelitian Rukmiyati dan Budiartha (2016), hasil penelitian kualitas sistem berpengaruh positif terhadap kepuasan pengguna. Hal ini sejalan dengan hasil penelitian yang dilakukan oleh Indriasari (2008), Saleh, Darwanis, dan Bakar (2012), dan Nursudi (2013). Namun, peneliti yang lain, seperti Harjito, Achyani, dan Payamta (2015) menyatakan kualitas sistem tidak 
berpengaruh terhadap kepuasan pengguna. Konflik signifikansi dan arah juga terjadi pada kualitas informasi terhadap kepuasan pengguna. Hasil penelitian Nursudi (2013) kualitas informasi berpengaruh positif terhadap kepuasan pengguna. Hal ini sejalan dengan penelitian Indriasari (2008), Saleh, et al. (2012) dan Rukmiyati dan Budiartha (2016). Namun, peneliti yang lain seperti Muharor, Busaini, dan Fitriah (2015) menyatakan kualitas informasi tidak berpengaruh terhadap kepuasan pengguna.

Peneliti menggunakan konstruk kegunaan persepsian seperti pada penelitian Rukmiyati dan Budiartha (2016) dan Palm, Colombet, Sicotte, dan Degoulet (2006) karena berpengaruh positif terhadap kepuasan pengguna. Selain itu, kegunaan persepsian merupakan indikator yang sesuai untuk mengukur sistem yang sifat penggunaannya sukarela maupun wajib (Peter, DeLone, dan McLean, 2008).

Permasalahan yang diteliti dapat dirumuskan dalam sebuah pertanyaan penelitian seberapa besar kesuksesan Sistem Informasi Keuangan Daerah (SIKD) jika dievaluasi dengan menggunakan model kesuksesan sistem informasi, dan melihat hubungan antar variabel menurut model tersebut. Model kesuksesan sistem informasi direpresentasikan oleh 5 konstruk, yaitu kualitas sistem, kualitas informasi, kualitas layanan, kegunaan persepsian, dan kepuasan pengguna Sistem Informasi Keuangan Daerah (SIKD). Penelitian ini bertujuan untuk membuktikan secara empiris pengaruh kualitas sistem, kualitas informasi, kualitas layanan, dan kegunaan persepsian terhadap kepuasan pengguna SIKD. Selain itu, penelitian ini juga meneliti peran mediasi kegunaan persepsian pada pengaruh kualitas sistem, kualitas informasi, kualitas layanan terhadap kepuasan pengguna SIKD.

Teori penerimaan pengguna terhadap suatu teknologi atau yang sering disebut Technology Acceptance Model (TAM) diperkenalkan oleh Davis (1989). Model ini dikembangkan dari Teori Tindakan Beralasan (Theory of Reasoned Action). Davis (1989) menyatakan penerimaan pengguna akan teknologi diukur dengan 2 konstruk penting, yaitu kegunaan persepsian dan kemudahan persepsian.

Model kesuksesan sistem informasi Delone dan McLean (2003) sering digunakan para peneliti untuk mengukur kesuksesan sistem informasi. Model ini merupakan pengembangan dari model kesuksesan sistem informasi tahun 1992. Yang membedakan model DM 2003 dan DM 1992, model ini menggabungkan 2 variabel individual impact dan organizational impact menjadi 1 variabel net benefit dan ditambahkan 1 variabel kualitas layanan sehingga model ini menggunakan 6 konstruk, yaitu information quality, system quality, service quality, intention to use, user satisfaction, dan net benefit. Penelitian DeLone dan McLean (2003) menjadi role model atau acuan peneliti untuk mengukur kesuksesan implementasi sistem informasi. Delone dan McLean (2003) mengungkapkan sistem informasi bisa dianggap sukses jika ada net benefit yang dihasilkan. Salah satu net benefit terhadap organisasi adalah peningkatan keuntungan organisasi (profit performance).

Hasil penelitian Saleh, et al. (2012) menyatakan kualitas sistem berpengaruh terhadap kepuasan pengguna. Hasil 
penelitian Nursudi (2013) menyatakan kualitas aplikasi, kualitas informasi, sumber daya manusia, dan layanan berpengaruh terhadap kepuasan pengguna sistem informasi, sedangkan dukungan manajemen tidak berpengaruh terhadap kepuasan pengguna sistem informasi. Penelitian yang dilakukan Karaman dan Bolen (2015) menunjukkan kualitas sistem, kualitas informasi, kualitas layanan, dan intensitas penggunaan berpengaruh terhadap kepuasan pengguna. Kualitas sistem dan kualitas informasi berpengaruh terhadap intensitas penggunaan namun kualitas layanan tidak berpengaruh terhadap intensitas penggunaan. Rukmiyati dan Budiartha (2016) menyatakan kualitas sistem, kualitas informasi, dan kegunaan persepsian berpengaruh terhadap kepuasan pengguna sistem informasi.

Peraturan Pemerintah No.56 Tahun 2005 menyatakan Sistem Informasi Keuangan Daerah (SIKD) adalah Sebuah sistem yang mendokumentasikan, mengadministrasikan, serta mengolah data pengelolaan keuangan daerah dan data terkait lainnya menjadi informasi yang disajikan kepada masyarakat dan sebagai bahan pengambilan keputusan dalam rangka perencanaan, pelaksanaan, dan pelaporan pertanggungjawaban pemerintah daerah. SIKD diperlukan dalam penyediaan informasi keuangan daerah yang komprehensif kepada masyarakat luas serta dasar bagi para pejabat pembuat kebijakan fiskal dalam membuat keputusan.

Pengukuran kesuksesan pada penelitian ini melihat dari perspektif pengguna, yaitu kepuasan pengguna sistem informasi. Penelitian ini mengacu pada teori penerimaan teknologi (Davis, 1989) yang diturunkan dari teori tindakan beralasan (TRA) yang menjelaskan bahwa perilaku seseorang dipengaruhi oleh minat. Pengguna sistem informasi akan puas jika komponenkomponen yang mendukung sistem informasi berkualitas dan pengguna merasakan manfaat atas sistem informasi tersebut. Peneliti menggunakan modifikasi model kesuksesan DeLone dan McLean (2003) dan model Seddon dan Kiew (1996). Konstruk yang digunakan, yaitu kualitas sistem, kualitas informasi, kualitas layanan, kegunaan persepsian, dan kepuasan pengguna.

Hal yang mendasari kegunaan persepsian sebagai variabel mediasi, Pertama konsep kemanfaatan sistem, jika sistem yang digunakan dapat memberikan manfaat maka akan meningkatkan kepuasan pengguna. Sebaliknya jika sistem tidak dirasakan manfaatnya maka akan menurunkan kepuasan penggunanya. Kedua, kegunaan persepsian dapat digunakan untuk mengukur sistem yang sifat penggunaannya wajib (mandatory) dan sukarela (voluntary) (Seddon dan Kiew, 1996). Beberapa penelitian kesuksesan sistem informasi menggunakan variabel minat (Intention) yang diukur dengan frekuensi atau intensitas penggunaan sebagai variabel mediasi. Konsepnya semakin sering sistem informasi digunakan maka pengguna semakin puas. Kondisi ini cocok jika sistem bersifat voluntary, akan tetapi akan menjadi berbeda jika penggunaan sistem bersifat mandatory. Oleh karena itu, sering atau tidaknya penggunaan sistem (frekuensi) tidak dapat dijadikan ukuran kepuasan pengguna.

Permasalahan yang diteliti dapat dirumuskan dalam sebuah pertanyaan 


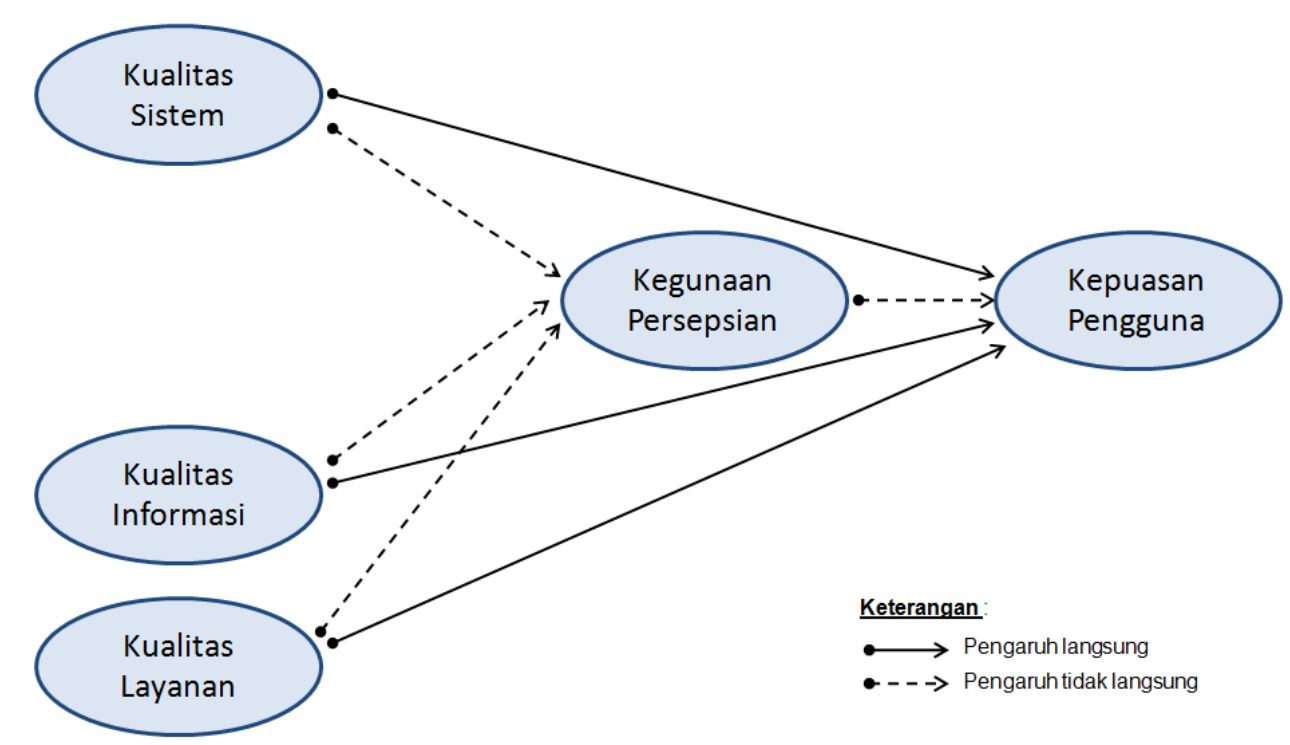

Gambar 2. Kerangka Konseptual

penelitian seberapa besar kesuksesan Sistem Informasi Keuangan Daerah (SIKD) jika dievaluasi dengan menggunakan model kesuksesan sistem informasi dan melihat hubungan antar variabel menurut model tersebut. Model kesuksesan sistem informasi direpresentasikan oleh 5 konstruk, yaitu kualitas sistem, kualitas informasi, kualitas layanan, kegunaan persepsian, dan kepuasan pengguna SIKD. Kerangka konseptual penelitian ditunjukkan pada Gambar 2.

Hipotesis yang akan diuji antara lain:

H1 : Kualitas Sistem berpengaruh positif terhadap Kepuasan Pengguna

H2 : Kualitas Informasi berpengaruh positif terhadap Kepuasan Pengguna

H3 : Kualitas Layanan berpengaruh positif terhadap Kepuasan Pengguna

H4 : Kegunaan Persepsian berpengaruh positif terhadap Kepuasan Pengguna

H5 : Kualitas Sistem berpengaruh tidak langsung terhadap Kepuasan Pengguna melalui Kegunaan Persepsian.

H6 : Kualitas Informasi berpengaruh tidak langsung terhadap Kepuasan Pengguna melalui Kegunaan Persepsian.
$\mathrm{H7}$ : Kualitas layanan berpengaruh tidak langsung terhadap Kepuasan Pengguna melalui Kegunaan Persepsian.

\section{METODE}

Jenis penelitian ini merupakan penelitian penjelasan (explanatory research), yang mencoba menjelaskan fenomena yang ada. Penelitian ini merupakan penelitian survei, populasi penelitian ini adalah semua staf pengelola keuangan daerah di seluruh Satuan Kerja Perangkat Daerah (SKPD) yang ada di wilayah Pemerintah Kota Batu. Populasi penelitian sejumlah 377 orang, sedangkan sampel penelitian sejumlah 147 orang. Metode sampling yang digunakan adalah metode nonprobability sampling, teknik sampling yang digunakan adalah metode purposive sampling dengan pertimbangan tertentu (judgment sampling). Skala pengukuran menggunakan skala Likert dengan rentang nilai 1 hingga 5. Skor 5 untuk tingkat persepsi Sangat Setuju, Setuju, Netral, Tidak Setuju, dan Tidak Setuju.

Kualitas sistem didefinisikan sebagai kualitas dari sistem teknologi informasi 
untuk dapat menghasilkan keluaran yang berkualitas. Kualitas informasi didefinisikan sebagai kualitas keluaran dari sistem informasi. Kualitas layanan didefinisikan seberapa baik dukungan tim TI di lapangan dalam rangka penyelenggaraan sistem informasi. Kegunaan persepsian didefinisikan sebagai tingkat kepercayaan pengguna bahwa sistem informasi yang digunakan akan membawa manfaat dan meningkatkan kinerjanya (Davis, 1989). Kepuasan pengguna didefinisikan sebagai perasaan akhir berupa rasa senang atau tidak senang yang dihasilkan interaksi dengan sistem (Seddon dan Kiew, 1996). Tahapan metode analisis data menggunakan analisa deskriptif dan analisa inferensial.
Analisis deskriptif digunakan untuk menjelaskan karakteristik responden meliputi jenis kelamin, usia, tingkat pendidikan, unit kerja (SKPD), jabatan, dan pengalaman bekerja menggunakan SIKD. Selain itu analisis deskriptif juga digunakan untuk menjelaskan tanggapan responden terhadap konstruk penelitian, meliputi: kualitas sistem, kualitas informasi, kualitas layanan, kegunaan persepsian, dan kepuasan pengguna.

Analisis inferensial yang digunakan untuk membuktikan hipotesis dalam penelitian ini adalah SEM (Structural Equation Modelling) dengan pendekatan PLS (Partial Least Square). Teknik resampling bootstrapping sejumlah 100 resample. Bootstrapping dipilih karena merupakan pilihan terbaik untuk

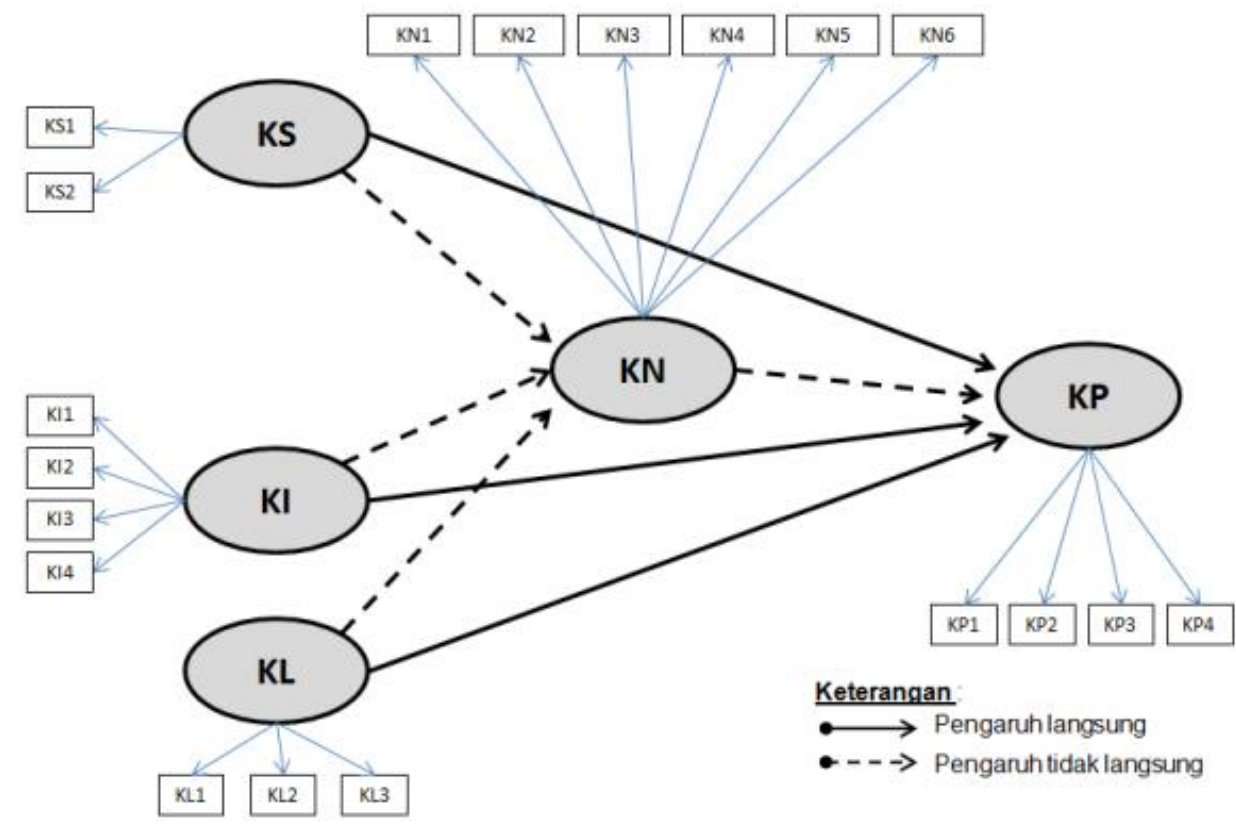

Gambar 3. Model penelitian

Keterangan:

$\mathrm{KP}=$ Kepuasan Pengguna

$\mathrm{KS}=$ Kualitas Sistem

$\mathrm{KI}=$ Kualitas Informasi

$\mathrm{KL}=$ Kualitas Layanan

$\mathrm{KN}=$ Kegunaan Persepsian

$\beta_{1} \ldots \beta_{10}=$ Koefisien jalur

$\zeta_{1 \ldots 3}=$ Tingkat kesalahan pengukuran 
ukuran sampel lebih dari 100 sampel (Sholihin dan Ratmono, 2013). Evaluasi model dalam analisis SEM-PLS dibagi atas evaluasi model pengukuran (Outer Model) dan evaluasi model struktural (Inner Model). Algoritma analisa outer model menggunakan PLS regression dan algoritma analisa inner model menggunakan Warp3.

Pengukuran indikator dan konstruk menggunakan uji validitas dan reliabilitas. Hal ini untuk mengetahui kemampuan indikator mengukur tiap konstruknya. Ada tiga kriteria yang dipakai untuk menilai outer model, yaitu convergen validity dan discriminant validity untuk setiap indikator, dan composite reliability untuk blok konstruk. Uji validitas konvergen dengan melihat nilai loading factor $>0,55$ dan $p$ values $<0,05$. Untuk menghindari indikasi kolinearitas lateral dilakukan penghapusan indikator dengan cross-loading $>0,5$. Uji validitas diskriminan dengan melihat nilai loading factor > cross-loading dan nilai akar kuadrat $A V E>$ korelasi antar konstruknya. Uji reliabilitas dengan melihat nilai composite reliability dan Cronbach's alpha $>0,7$.

Evaluasi model struktural (inner model) digunakan untuk memprediksi hubungan antar konstruk. Evaluasi dilakukan dengan melihat $R$-Squared untuk setiap konstruk endogen sebagai kekuatan prediksi dari model struktural dan melihat $\mathrm{Q}^{2}$ untuk predictive relevance atau predictive sample reuse. Gambar model penelitian ditunjukkan pada Gambar 3.

Pengujian dan pengambilan simpulan terkait mediasi melalui WarpPLS 5.0 menggunakan prosedur yang dikembangkan Baron dan Kenny (1986) dalam Sholihin dan Ratmono (2013:56-57). Hipotesis dalam penelitian ini merupakan hipotesis yang telah diberi arah (one-tailed) pada hipotesis 1, 2, 3, dan 4, sedangkan hipotesis 5, 6, dan 7 tidak diberikan arah (two-tailed). Ketentuan diterimanya hipotesis alternatif dapat dilihat apabila nilai $\mathrm{Ha}<0,05$

\section{HASIL DAN PEMBAHASAN}

Sampel adalah 147 staf pengelola keuangan daerah yang berinteraksi dan memiliki pengalaman menggunakan SIKD paling kurang 6 bulan lamanya. Prosedur pemilihan sampel ditunjukkan pada Tabel 2 . Selanjutnya karakteristik responden ditunjukkan pada Tabel 3.

Hasil uji validitas konvergen menunjukkan semua indikator memiliki nilai loading factor $>0,55$ dan $p$-values $<0,05$

Tabel 2. Prosedur pemilihan sampel

\begin{tabular}{clc}
\hline No & \multicolumn{1}{c}{ Keterangan } & Jumlah Sampel \\
\hline 1 & $\begin{array}{l}\text { Jumlah pegawai di bagian keuangan pada seluruh } \\
\text { SKPD }\end{array}$ & 377 \\
2 & $\begin{array}{l}\text { Jumlah pegawai yang tidak berinteraksi langsung } \\
\text { dengan SIKD }\end{array}$ & $(215)$ \\
3 & $\begin{array}{l}\text { Jumlah pegawai yang berinteraksi langsung } \\
\text { dengan SIKD }\end{array}$ & 162 \\
4 & $\begin{array}{l}\text { Pengguna SIKD yang tidak memenuhi kriteria } \\
\text { (lama pengalaman di bawah 6 bulan) }\end{array}$ & $(14)$ \\
5 & $\begin{array}{l}\text { Di drop karena data tidak lengkap } \\
\text { Sampel akhir }\end{array}$ & $(1)$ \\
\hline
\end{tabular}


Tabel 3. Karakteristik responden

\begin{tabular}{|c|c|c|c|}
\hline \multirow{2}{*}{ No } & \multirow{2}{*}{ Jenis Kelamin } & \multicolumn{2}{|c|}{ Frekuensi } \\
\hline & & Orang & Persentase (\%) \\
\hline & Pria & 87 & $59,18 \%$ \\
\hline & Wanita & 60 & $40,82 \%$ \\
\hline Jum & & 147 & 100,00 \\
\hline \multirow{2}{*}{ No } & \multirow{2}{*}{ Usia } & \multicolumn{2}{|c|}{ Frekuensi } \\
\hline & & Orang & Persentase (\%) \\
\hline 1 & 21 - 30 Tahun & 10 & 6,80 \\
\hline 2 & 31 - 40 Tahun & 117 & 79,59 \\
\hline & 41 - 50 tahun & 20 & 13,61 \\
\hline \multicolumn{2}{|c|}{ Jumlah } & 147 & 100,00 \\
\hline \multirow{2}{*}{ No } & \multirow{2}{*}{ Pendidikan } & \multicolumn{2}{|c|}{ Frekuensi } \\
\hline & & Orang & Persentase (\%) \\
\hline 1 & SMA & 18 & 12,24 \\
\hline 2 & DIII & 5 & 3,40 \\
\hline 3 & S1 & 109 & 74,15 \\
\hline 4 & S2 & 15 & 10,20 \\
\hline Jum & & 147 & 100,00 \\
\hline \multirow{2}{*}{ No } & \multirow{2}{*}{$\begin{array}{c}\text { Pengalaman menggunakan } \\
\text { SIKD }\end{array}$} & \multicolumn{2}{|c|}{ Frekuensi } \\
\hline & & Orang & Persentase (\%) \\
\hline 1 & 6 - 12 Bulan & 15 & 10,20 \\
\hline 2 & $>1$ Tahun & 132 & 89,80 \\
\hline \multicolumn{2}{|c|}{ Jumlah } & 147 & 100,00 \\
\hline
\end{tabular}

sehingga 19 indikator memenuhi syarat validitas konvergen. Selanjutnya saat uji kolinearitas ditemukan 1 indikator dengan cross-loading $>0,5$ yaitu KL5 sehingga diputuskan dihapus dan jumlah indikator menjadi 18 indikator. Pada uji validitas diskriminan semua indikator nilai loading factor sudah lebih besar dari cross-loading dan akar kuadrat AVE sudah lebih besar dari korelasi antar konstruknya sehingga 18 indikator dinyatakan valid. Tahap Selanjutnya dilakukan uji reliabilitas konstruk, berdasarkan uji reliabilitas didapatkan nilai composite reliability dan Cronbach's alpha $>0,7$ sehingga konstruk dinyatakan reliabel.
Evaluasi model struktural dengan menggunakan PLS dilakukan dengan melihat $R$-squared dan Q-squared. Nilai $R$-Squared sebesar 0,776 menunjukkan konstruk kepuasan pengguna dijelaskan sebesar $77,60 \%$ oleh kualitas sistem, kualitas informasi, kualitas layanan, dan kegunaan persepsian, sedangkan 22,40\% dijelaskan oleh variabel lain di luar penelitian. Hasil estimasi model memiliki predictive relevance yang baik dengan nilai $Q$-squared 0,746.

Pengujian efek mediasi menggunakan 2 tahapan, pertama, menguji pengaruh langsung variabel independen terhadap variabel dependen, dilanjutkan menguji pengaruh variabel independen terhadap 
Tabel 4. Hasil pengujian efek mediasi

\begin{tabular}{|c|c|c|}
\hline \multicolumn{3}{|c|}{ Pengaruh Langsung } \\
\hline \multirow{2}{*}{ Konstruk } & \multicolumn{2}{|c|}{ Koefisien Jalur } \\
\hline & & $\mathrm{KP}$ \\
\hline KS & & 0,152 \\
\hline $\mathrm{KI}$ & & $0,617^{*}$ \\
\hline $\mathrm{KL}$ & & 0,076 \\
\hline \multicolumn{3}{|c|}{ Simultan (Full Model) } \\
\hline \multirow{2}{*}{ Konstruk } & \multicolumn{2}{|c|}{ Koefisien Jalur } \\
\hline & $\mathrm{KN}$ & $\mathrm{KP}$ \\
\hline $\mathrm{KI}$ & $0,667^{*}$ & $0,296^{*}$ \\
\hline $\mathrm{KN}$ & & $0,634^{*}$ \\
\hline
\end{tabular}

variabel mediasi. Kedua, menguji secara simultan variabel independen, mediasi, dan dependen. Hasil pengujian efek mediasi ditunjukkan pada Tabel 4.

Pengambilan simpulan tentang mediasi sesuai dengan Sholihin dan Ratmono (2013:57) sebagai berikut:

1. Kegunaan Persepsian (KN) tidak memediasi pengaruh Kualitas Sistem (KS) terhadap Kepuasan Pengguna (KP). Hal ini dibuktikan pada langkah pertama, KS $\rightarrow \mathrm{KP}$ tidak signifikan. Berdasarkan uji mediasi yang telah dilakukan, hipotesis ke 5 dinyatakan ditolak.

2. Kegunaan Persepsian (KN) memediasi secara parsial pengaruh Kualitas Informasi (KI) terhadap Kepuasan Pengguna (KP). Hal ini dibuktikan saat nilai koefisien jalur setelah mediasi < nilai koefisien sebelum mediasi (pengaruh langsung) tetapi tetap signifikan. Hal ini menununjukkan kegunaan persepsian memediasi parsial pengaruh kualitas informasi terhadap kepuasan pengguna. Berdasarkan hasil uji mediasi membuktikan hipotesis ke 6 diterima.

3. Kegunaan Persepsian (KN) tidak memediasi pengaruh Kualitas Layanan (KL) terhadap Kepuasan Pengguna (KP).
Hal ini dibuktikan pada langkah pertama, $\mathrm{KL} \rightarrow \mathrm{KP}$ tidak signifikan. Berdasarkan uji mediasi yang telah dilakukan, hipotesis ke 7 dinyatakan ditolak

Pengujian hipotesis dilakukan dengan mengevaluasi nilai koefisien jalur dan $p$ values. Koefisien jalur menunjukkan arah hubungan antar konstruk, sedangkan $p$ values menunjukkan tingkat signifikansi hubungan antar konstruk. Hipotesis 1,2,3, dan 4 menggunakan arah (positif), sedangkan hipotesis 5,6, dan 7 tidak menggunakan arah. Hipotesis diterima jika koefisien jalur sesuai dengan arah hipotesis dan $p$-values $<0,05$.

Hipotesis 1 menyatakan bahwa kualitas sistem berpengaruh positif terhadap kepuasan pengguna. Hasil pengujian menunjukkan $p$-values yang dihasilkan sebesar 0,098 sehingga H1 ditolak. Kualitas sistem tidak berpengaruh terhadap kepuasan pengguna. Baik atau buruknya sistem bukan fokus utama dan tidak memengaruhi kepuasan pengguna Sistem Informasi Keuangan Daerah (SIKD) di Kota Batu. Pengguna SIKD di Kota Batu lebih mementingkan output yang dihasilkan oleh sistem daripada kualitas sistem itu sendiri. Selama output sesuai dengan harapan, 
kepuasan pengguna akan meningkat. Alasan lain karena pengelola keuangan dalam melakukan tugasnya tidak hanya berinteraksi dengan SIKD saja namun ada beberapa pekerjaan yang harus dikerjakan dan diselesaikan tanpa menggunakan sistem informasi berbasis teknologi. Hal ini yang mendasari baik buruknya kualitas sistem tidak berpengaruh terhadap kepuasan pengguna.

Hipotesis 2 menyatakan kualitas informasi berpengaruh positif terhadap kepuasan pengguna. Hasil pengujian menunjukkan $p$-values yang dihasilkan $<0,001$ sehingga $\mathrm{H} 2$ diterima. Kualitas sistem berpengaruh positif terhadap kepuasan pengguna. Semakin baik kualitas informasi akan semakin meningkatkan kepuasan pengguna. Informasi yang berkualitas diukur dari ketepatan waktu penyajian, relevan, detail dan benar, dan konsisten. Informasi yang berkualitas dapat digunakan sebagai dasar membuat keputusan strategis yang dapat memberikan nilai tambah bagi organisasi. Sebaliknya jika kualitas informasi buruk atau informasi tidak relevan, informasi tersebut tidak dapat digunakan sebagai dasar membuat keputusan. Informasi yang tidak berkualitas akan menurunkan kepuasan pengguna.

Hipotesis 3 menyatakan kualitas layanan berpengaruh positif terhadap kepuasan pengguna. Hasil pengujian menunjukkan pvalues sebesar 0,193 sehingga H3 ditolak. Kualitas layanan tidak berpengaruh terhadap kepuasan pengguna. Hal ini disebabkan karena pengguna SIKD menganggap layanan yang diberikan oleh tim TI bukan bagian dari penyelenggaraan sistem informasi. Baik atau buruknya kualitas layanan tidak memengaruhi kepuasan pengguna. Alasan lain penyedia layanan SIKD di Pemerintah Kota Batu adalah staf Badan Keuangan Daerah (BKD) yang merangkap tugas sebagai tim TI SIKD. Jadi, tim TI di sini bukan tim TI profesional yang tugas pokoknya menyelenggarakan SIKD namun tim TI ini sehari-harinya masih mengerjakan pekerjaan rutin di Badan Keuangan Daerah (BKD) Kota Batu. Pada akhirnya pengguna SIKD menilai masih ada bias tugas antara staf BKD dan sebagai Tim TI. Hal ini menyebabkan kepuasan pengguna tidak dipengaruhi oleh kualitas layanan.

Hipotesis 4 menyatakan kegunaan persepsian berpengaruh positif terhadap kepuasan pengguna. Hasil pengujian menunjukkan p-values sebesar <0,001 sehingga $\mathrm{H} 4$ diterima. Sistem informasi disebut bermanfaat jika dapat menyelesaikan tugas lebih cepat, meningkatkan kinerja, produktivitas, efektivitas, mempermudah penyelesaian pekerjaan, dan secara keseluruhan bermanfaat. Semakin bermanfaat suatu sistem informasi maka semakin puas penggunanya. Sebaliknya, sistem informasi yang tidak bermanfaat menyebabkan menurunnya tingkat kepuasan. Responden penelitian merasakan bahwa SIKD yang digunakan bermanfaat dan meningkatkan kinerjanya sehingga berdampak pada meningkatnya kepuasan pengguna.

Hipotesis 5 kualitas sistem berpengaruh tidak langsung terhadap kepuasan pengguna melalui kegunaan persepsian. Hasil pengujian menyatakan $\mathrm{H} 5$ ditolak. Kegunaan persepsian tidak berhasil memediasi pengaruh kualitas sistem terhadap kepuasan pengguna. Hal ini disebabkan kepercayaan 
pengguna atas sistem informasi yang bermanfaat dan dapat meningkatkan kinerja itu bukan karena sistem yang berkualitas. Sehingga baik buruknya kualitas sistem tidak mampu memengaruhi kepuasan pengguna. Pengguna SIKD menganggap kualitas sistem bukan sesuatu yang penting dan prioritas. Hal ini disebabkan pengguna lebih fokus pada kualitas informasi yang dihasilkan oleh sistem daripada kualitas sistem itu sendiri. Pertimbangan lain dikarenakan ada beberapa pekerjaan teknis pengelola keuangan yang penyelesaiannya dilakukan secara manual tanpa menggunakan sistem informasi berbasis teknologi.

Hipotesis 6 kualitas informasi berpengaruh tidak langsung terhadap kepuasan pengguna melalui kegunaan persepsian. Hasil pengujian menunjukkan $\mathrm{H} 6$ diterima. Kegunaan persepsian berhasil memediasi secara parsial pengaruh kualitas informasi terhadap kepuasan pengguna. Semakin baik kualitas informasi akan meningkatkan kepercayaan penggunanya bahwa informasi yang digunakan sebagai dasar pengambilan keputusan semakin baik dan pada akhirnya berdampak meningkatkan kepuasan pengguna. Sebaliknya informasi yang tidak berkualitas/tidak relevan akan menurunkan tingkat kepercayaan penggunanya bahwa informasi yang dihasilkan sistem tidak bermanfaat dan tidak meningkatkan kinerjanya sehingga berdampak menurunnya kepuasan pengguna. Bentuk partial mediation menunjukkan bahwa kegunaan persepsian bukan satu-satunya pemediasi hubungan kualitas informasi terhadap kepuasan pengguna namun terdapat faktor pemediasi yang lain.
Hipotesis 7 kualitas layanan berpengaruh tidak langsung terhadap kepuasan pengguna melalui kegunaan persepsian. Hasil pengujian menyatakan $\mathrm{H} 7$ ditolak. Hal ini disebabkan kepercayaan pengguna atas sistem informasi yang bermanfaat dan dapat meningkatkan kinerja itu bukan karena dukungan atau support dari tim TI. Sehingga baik buruknya kualitas layanan yang diberikan Tim TI tidak mampu memengaruhi kepuasan pengguna. Tim TI yang menyediakan layanan SIKD di Pemerintah Kota Batu bukan Tim TI profesional yang pekerjaan dan fokus utamanya memberikan layanan terkait penyelenggaraan SIKD. Tim TI ini adalah staf Badan Keuangan Daerah (BKD) yang juga mengerjakan pekerjaan rutin di BKD. Hal ini menyebabkan bias tugas antara sebagai staf BKD dengan sebagai Tim TI penyelenggara SIKD. Pada akhirnya pengguna tidak menganggap bahwa layanan yang diberikan adalah bagian dari penyelenggaraan SIKD.

\section{SIMPULAN}

Hasil penelitian ini memberikan bukti empiris bahwa kepuasan pengguna sistem informasi dipengaruhi oleh kualitas informasi dan kegunaan persepsian. Pemerintah daerah sebagai penyelenggara Sistem Informasi Keuangan Daerah (SIKD) harus memperhatikan beberapa faktor penting tersebut untuk mewujudkan kesuksesan implementasi SIKD. Faktor-faktor penting di antaranya kualitas informasi, kegunaan persepsian, dan kepuasan pengguna. Untuk meningkatkan kualitas informasi diperlukan ketepatan waktu pada saat penyajian informasi, informasi yang disajikan relevan, detail dan benar, dan konsisten. Untuk 
meningkatkan kepercayaan pengguna, SIKD harus dapat menyelesaikan tugas dengan cepat, dapat meningkatkan kinerja, produktivitas, efektivitas, mempermudah pekerjaan, dan bermanfaat bagi penggunanya. Pengukuran kesuksesan sistem informasi tidak terbatas pada teknis kualitas informasi saja, faktor penting lainnya adalah feedback dari manusia yang menggunakannya, yaitu kegunaan persepsian dan kepuasan pengguna. Temuan ini sejalan Doll dan Torkzadeh (1988) yang menyatakan kesuksesan atau kegagalan implementasi sistem informasi diukur dari kepuasan pengguna.

Sebaliknya kepuasan pengguna tidak ditentukan oleh kualitas sistem dan kualitas layanan. Baik buruknya kualitas sistem dan layanan tidak memengaruhi kepuasan pengguna. Pertama, apabila pengguna sistem informasi memiliki beberapa pekerjaan yang penyelesaiannya tanpa menggunakan sistem informasi atau masih menggunakan cara-cara manual maka dapat dipastikan baik buruknya kualitas sistem tidak dapat mempengaruhi kepuasan pengguna. Kedua, apabila penyedia layanan ini bukan Tim TI profesional yang tugas utamanya sebagai penyedia layanan TI maka dipastikan baik buruknya layanan juga tidak dapat memengaruhi kepuasan pengguna sistem informasi.

Kegunaan persepsian berhasil memediasi pengaruh tidak langsung kualitas informasi terhadap kepuasan pengguna. Hal ini dapat dikatakan bahwa informasi yang berkualitas akan meminimalisasi terjadinya masalah dalam pengambilan keputusan, bermanfaat, dan meningkatkan kinerja penggunanya, dan hal tersebut pada gilirannya menjelaskan mengapa kepercayaan pengguna atas sistem informasi meningkat. Meningkatnya kepercayaan pengguna tersebut pada akhirnya berdampak meningkatkan kepuasan pengguna sistem informasi. Sebaliknya kualitas informasi yang buruk (tidak relevan dan tidak konsisten) menyebabkan keputusan atau kebijakan menjadi tidak tepat sasaran, merugikan dan tidak membawa manfaat sehingga pada akhirnya menurunkan kepuasan pengguna.

\section{DAFTAR PUSTAKA}

Adji, Y. (2016). Server gangguan, pencetakan e-KTP Subang terhambat. Retrieved July 25, 2017, from http://www.pikiranrakyat.com

Al-Adaileh, R.M. (2009). An Evaluation of Information Systems Success: A User Perspective: The Case of Jordan Telecom Group. European Journal of Scientific Research, 37(2), 226-239.

Davis, F. (1989). Perceived Usefulness, Ease of Use, and User Acceptance of Information Technology. MIS Quarterly, 13(3), 319-340.

DeLone, W.H., \& McLean, E.R. (2003). The DeLone and McLean Model of Information Systems Success: A Ten-Year Update. Journal of Management Systems, 19(4), 9-30.

Dia. (2014). Musim lelang LPSE tidak dapat diakses. Retrieved July 25, 2017, from http://www.korankaltim.com

Doll, W.J. \& Torkzadeh, G. (1988). The Measurement of End-user Computing Satisfaction. MIS Quarterly, 12(2), 259274.

Gautama, W. (2016). Ini Penjelasan Dispenda Mengenai Gangguan Server di Kantor Samsat Rajabasa. Retrieved July 25, 2017, from http://www.tribunnews.com 
Harjito, Y., Achyani, F., \& Payamta (2015). Implementasi E-Procurement Ditinjau Dari Kesuksesan Sistem Teknologi Informasi Dengan Menggunakan Model Delone dan McLean. Jurnal Ekonomi dan Bisnis, 18(1), 61-82.

Hartono, J. (2007) Sistem Informasi Keperilakuan. Yogyakarta, Indonesia: Andi.

Indriasari, R. (2008). Pengaruh Kualitas Sistem, Kualitas Informasi dan Penggunaan Nyata Terhadap Kepuasan Pemakai: Studi pada Pemerintah Propinsi Sulawesi Tengah. Unpublished Thesis, Universitas Brawijaya, Malang.

Jamaludin, F. (2015). Pendaftaran online SDN di Jakarta alami gangguan. Retrieved July 25, 2017, from https://www. merdeka.com

Karaman, E., \& Bolen, M.C. (2015). Validating Information Systems Success Model Within Open Educational Context. Ekev Akademi Dergisi, 19(64), 101-114.

KPPNJKTVII. (2016) Pemberitahuan gangguan pada jaringan SPAN. Retrieved July 25, 2017, from http://kppnjakarta7.net

Muharor, A., \& Busaini, F. (2015). Determinan Kesuksesan Aplikasi SIA Komdanas Pada Satuan Kerja Di Koordinator Wilayah Pengadilan Tinggi Mataram. Jurnal InFestasi, 11(2), 151170.

Nursudi. (2013). Faktor-Faktor Yang Mempengaruhi Tingkat Kepuasan Pengguna Aplikasi Pelaporan Keuangan Pemerintah. Diponegoro Journal of Accounting, 2(3),1-12.

Palm, J.M., Colombet, I., Sicotte, I., \& Degoulete, P. (2006). Determinants of User Satisfaction with a Clinical
Information Systems. Proceedings of the American Medical Informatics Association, (pp. 614-618).

Peter, S., DeLone, W., \& McLean, E. (2008). Measuring information systems success: models, dimensions, measures, and interrelationships. European Journal of Information Systems, 17, 236-263.

Redaksi. (2016). Data center rusak, layanan pabean terganggu. Retrieved July 25, 2017, from http://koran.bisnis.com

Republik Indonesia. 2005. Peraturan Pemerintah No.56 Tahun 2005 tentang Sistem Informasi Keuangan Daerah. Lembaran Negara RI Tahun 2005, No.138. Sekretariat Negara RI. Jakarta.

Rukmiyati \& Budiartha. (2016). Pengaruh Kualitas Sistem Informasi, Kualitas Informasi dan Perceived Usefulness pada Kepuasan Pengguna Akhir Software Akuntansi: Studi Empiris pada Hotel Berbintang di Provinsi Bali. E-Jurnal Ekonomi dan Bisnis Universitas Udayana, 5(1),115-142.

Saleh, Darwanis, \& Bakar, U. (2012). Pengaruh Kualitas Sistem Informasi terhadap Kualitas Informasi Akuntansi Dalam Upaya Meningkatkan Kepuasan Pengguna Software Akuntansi pada Pemerintah Aceh. Jurnal Akuntansi Pascasarjana Universitas Syiah Kuala, 1(1), 110-124

Seddon, P.B., \& Kiew, M.Y. (1996). A Partial Test and Development of DeLone and McLean's Model of IS Success. Australian Journal of Information Systems, 4(1), 90109.

Sholihin, M., \& Ratmono, D. (2013). Analisis SEM-PLS dengan WarpPLS 3.0 Untuk Hubungan Nonlinier dalam Penelitian Sosial dan Bisnis. Yogyakarta: Penerbit Andi. 